\title{
Tectonic history of seismogenic fault structures in Central Iran
}

\author{
Soheyla BEYGI, Alireza NADIMI*, Homayon SAFAEI \\ Department of Geology, Faculty of Sciences, University of Isfahan, Hezarjrib, P.O. Box 81746-73441, Isfahan, Iran; a.nadimi@sci.ui.ac.ir \\ * Corresponding author
}

\begin{abstract}
In this paper, we use satellite images, field observations and aeromagnetic data to describe major tectonic features in the central portion of the Urumieh-Dokhtar Magmatic Arc (UDMA) in Central Iran. Most of the analyzed structures such as horsetail splays, rotated blocks, positive flower structures and sedimentary basins have not been previously recognized. The NW-SE-trending Zefreh Fault is the most important dextral transpressional active lineament in the area. Maps of filtered aeromagnetic anomalies confirmed that the fault also affects the basement. Based on our field observations and cross-cutting relationships, tectonic evolution of the central part of the UDMA is interpreted in terms of two main stages: (1) formation of main thrusts during shortening and exhumation of older rocks in the UDMA after Eocene-Oligocene, and (2) transpressional movements reactivating the main thrust faults to reverse-dextral strike-slip faults during the Pliocene-Quaternary. The present-day deformation of the UDMA is mostly dominated by strike-slip movements. These two stages are interpreted as reflecting a change in convergence vector between Arabian and Eurasian plates.
\end{abstract}

Keywords: Central Iran, collisional orogeny, plate convergence, strike-slip fault, Urumieh-Dokhtar Magmatic Arc, Zagros Orogenic Belt Received: 5 October, 2015; accepted: 7 April, 2016; handling editor: J. Žák

\section{Introduction}

The Cenozoic deformation in Iran is the result of the Arabia-Eurasia convergence that culminated with their collision during the Eocene to Oligocene times (e.g. Allen et al. 2004; Agard et al. 2011; Mouthereau et al. 2012). Late Cenozoic strike-slip tectonics and active faulting in Iran have been extensively studied in the last decades. The active strike-slip tectonics is controlled by the northward motion of the Arabian Plate with respect to Eurasia (Vernant et al. 2004). Global Positioning System (GPS) vectors indicate a NNE motion of the Arabian Plate relative to Eurasia at a rate of about $22 \pm 2 \mathrm{~mm} / \mathrm{yr}$ along the $51^{\circ}$ east longitude (Vernant et al. 2004). This convergence rate, between the Central Iranian Block and the central Zagros, is about $7 \pm 2 \mathrm{~mm} / \mathrm{yr}$. In the $\mathrm{N}$, shortening occurred at a rate of $8 \pm 2 \mathrm{~mm} / \mathrm{yr}$ between the Central Iranian Block and the Alborz Mountains (Vernant et al. 2004). Slower deformation occurs in Central Iran, south of Alborz and north of the Sanandaj-Sirjan zone (SSZ) at a rate of $3 \pm 2 \mathrm{~mm} / \mathrm{yr}$ (Vernant et al. 2004; Jamali et al. 2010).

Allen et al. (2011) suggested that changes in the N-S Arabia-Eurasia convergence in Central Iran were partitioned via dextral faults and thrusting, similar to the situation in Zagros or Alborz. In this respect, the dextral strike-slip faulting is thought to accommodate the NWSE orogen-parallel component of the N-S convergence (Mouthereau et al. 2012). Thrusting that accommodates the NE-SW orogen-normal shortening was studied independently by Mouthereau (2011) in order to model the distribution of crustal thickening across the whole colli- sion zone. These two models explain well the long-term $\mathrm{N}-\mathrm{S}$ convergence taken up in the Central Iran.

As noted by Allen et al. (2004, 2011) deformation by strike-slip faulting and thrusting seems to have slowed in Central Iran. This was possibly related to a change in boundary conditions in the E, associated with the onset of the Afghan-India collision at 5-2 Ma that stopped lateral extrusion/escape (Mouthereau et al. 2012). Here, in accord with the partitioning model of Allen et al. (2011), in which orogen-parallel lengthening is limited, Mouthereau et al. (2012) proposed that the transition was progressive since 15-10 Ma being related to arc-normal thickening, which led to the uplift of the Iranian Plateau and to the cessation of active deformation in Central Iran. The progressive thickening in the Iranian Plateau possibly terminated activity along NNW-SSE strike-slip faults such as the Dehshir or Anar faults (Mouthereau et al. 2012). Mouthereau et al. (2012) also concluded that the overall long-term distribution of deformation in the Zagros collision zone may be understood in the context of the N-S indentation of Arabia continent into Eurasia.

In this paper, we describe and interpret the structural architecture and kinematics in the Ardestan region of West Central Iran (Figs 1-2). The main aim of this study is to analyze seismogenic fault structures and correlate them with geological information and aeromagnetic data, in order to define the local fault patterns both in the surface and in the subsurface, which have been responsible for the structural development of the area. These new results are used to revise the kinematic context of the central part of the Urumieh-Dokhtar Magmatic Arc 


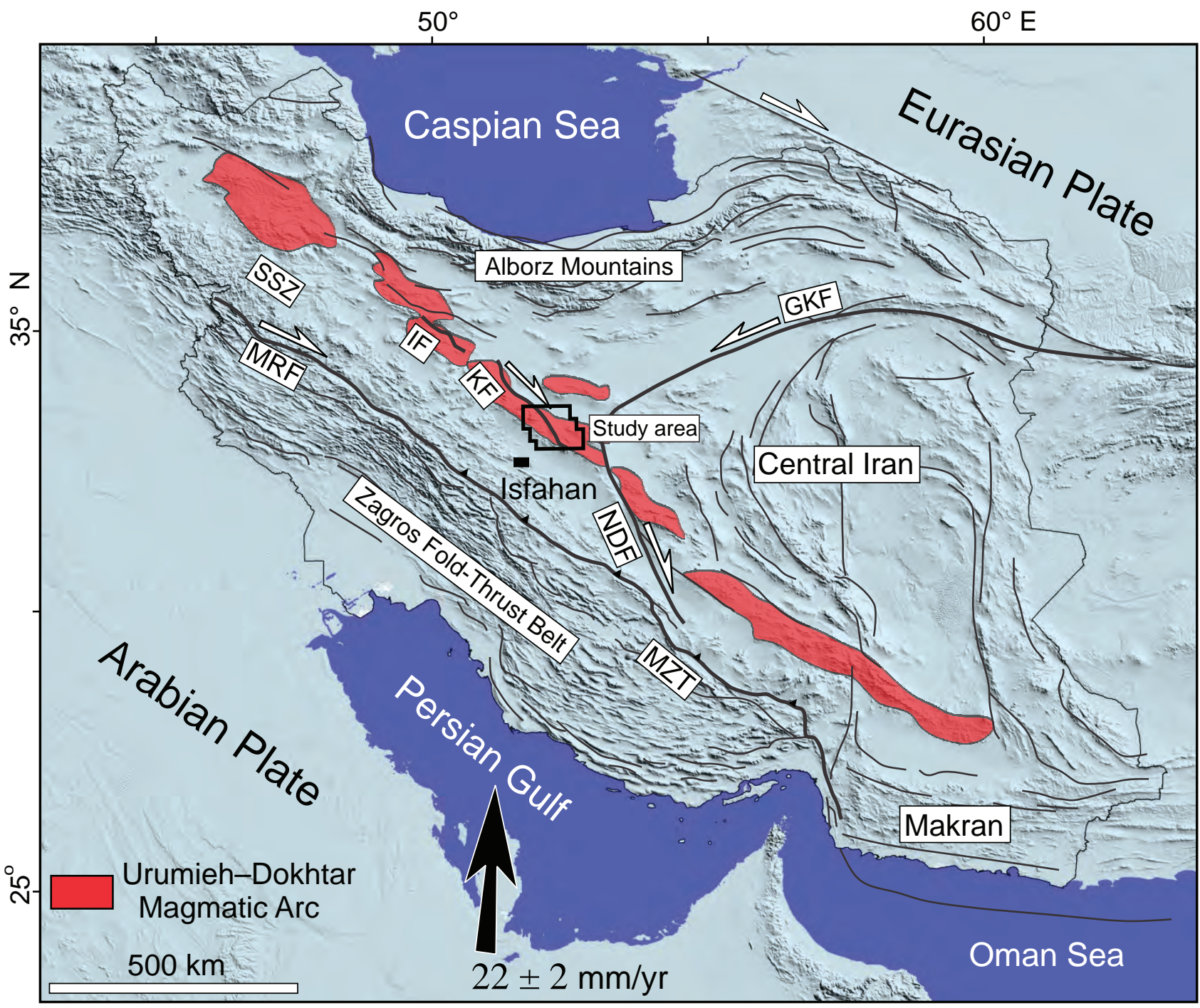

Fig. 1 Main tectonostratigraphic zones of Iran (modified from Aghanabati 2004) and location of study area. Major faults discussed in the text are shown. Black arrow denotes motion of the Arabian Plate relative to Eurasia from Vernant et al. (2004). SSZ - Sanandaj-Sirjan Zone, MZT - Main Zagros Thrust, MRF - Main Recent, GKF - Great Kavir (Doruneh), NDF - Nain-Dehshir, IF- Indes and KF- Kashan faults.

(UDMA), with implications on the overall kinematic and tectonic framework of the Central Iran.

\section{Geological setting}

\subsection{Tectonics}

The UDMA is a subduction-related magmatic belt in West Central Iran, which is a part of the Zagros Orogen (Alavi 1994) (Fig. 1). It is generally assumed that the UDMA was a magmatic arc overlying the slab of Neo-Tethyan oceanic lithosphere, which was subducted beneath the Central Iran (Berberian and Berberian 1981; Alavi 1994; Agard et al. 2005). The UDMA hosts abundant Cenozoic magmatic rocks, dominantly of arc (Berberian and Berberian 1981; Berberian et al. 1982; Emami 2000) or island-arc type (Shahabpour 2005). The peak volcanic activity was in Eocene (Farhoudi 1978; Berberian and King 1981; Shahabpour 2005), with the oldest units dating back to Early Eocene time (Ypresian; c. 55-50 Ma, Emami 2000). The arc rocks themselves comprise various intrusive and extrusive units including gabbros, diorites, granodiorites and granite bodies of different sizes and ages (e.g. Haghipour and Aghanabati 1985) and basaltic lavas, trachybasalts, ignimbrites and pyroclastic rocks (mostly tuffs and agglomerates) (Alavi 1994) (Fig. 2).

\subsection{Lithostratigraphy}

The Eocene-Miocene UDMA was emplaced into sedimentary and metasedimentary basement successions of Paleozoic and Mesozoic age. The oldest exposed rocks are dark limestones and dolomites of Cambrian, Devonian 


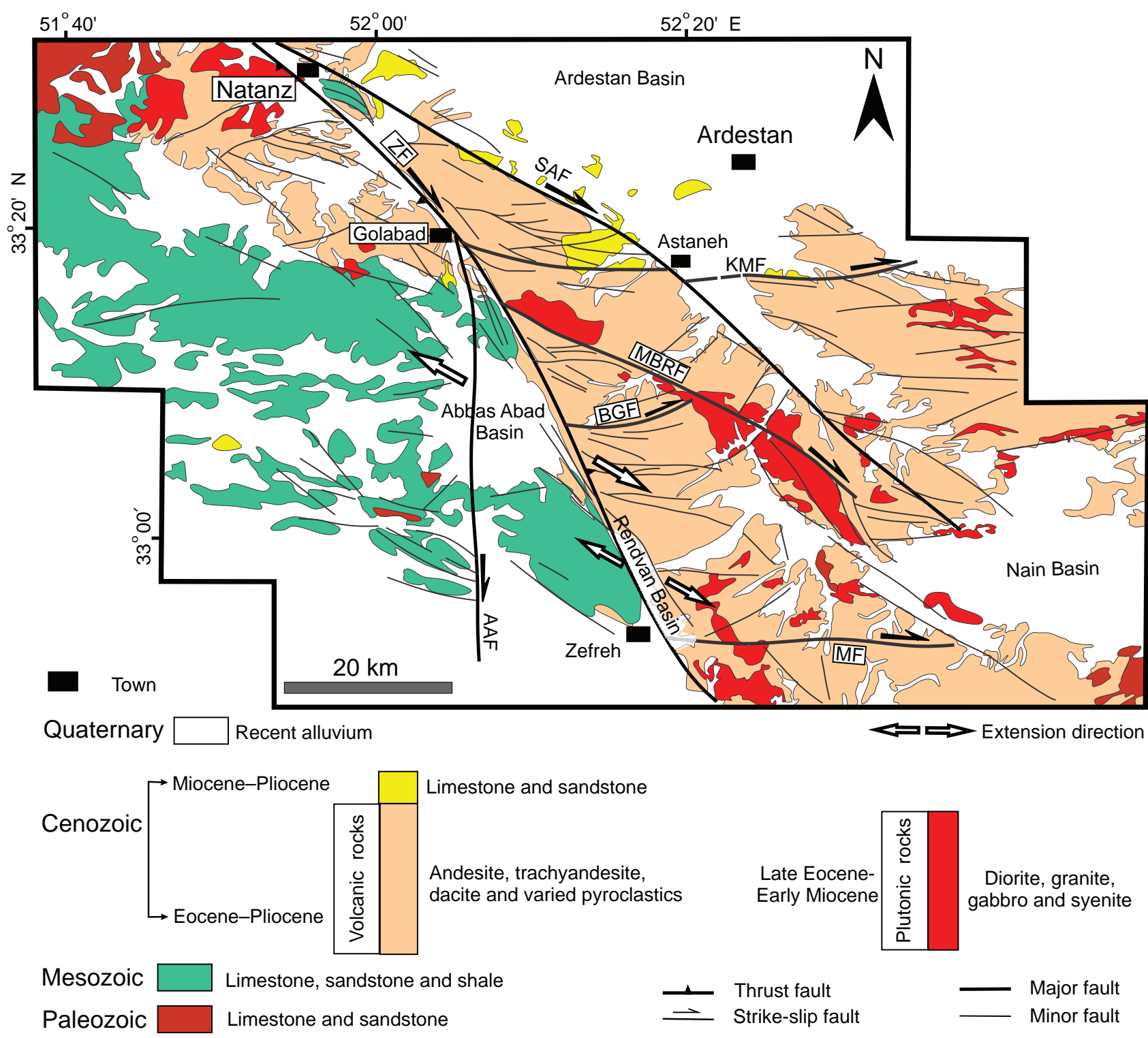

Fig. 2 Geological map and fault patterns of the central part of the UDMA. Major faults: Zefreh (ZF), South Ardestan (SAF), Marbin Rangan (MBRF), Abbas Abad (AAF), Kacho Mesghal (KMF), Bar Gohar (BGF) and Marshenan (MF) (Zahedi and Amidi 1991; Radfar et al. 1999, 2002).

and Permian age, Mesozoic sedimentary rocks comprise limestones, shales, marls, sandstones and conglomerates. Spatially, the Paleozoic and Mesozoic basement units are exposed over the southwestern part of the Zefreh Fault, while the Eocene volcanic rocks are restricted to the northeastern side of the structure suggesting both southwestside-up offset due to thrusting on the Zefreh Fault and/ or advection and juxtaposition of blocks due to dextral strike-slip on the structure contemporaneous after the onset of the volcanism (Radfar et al. 1999, 2002) (Fig. 2).

In addition to the basement rocks and igneous units of the UDMA, the area was covered by marine and continental sedimentary successions during the Cenozoic. The latest marine transgression in Central Iran occurred along northeasterly depressions (a back-arc basin) where Oligo-
cene-Miocene reefal limestones and green marls of the Qom Fm. were deposited (e.g. Berberian and King 1981; Morley et al. 2009). This formation rests unconformably on older units in the northern and eastern parts of the study area. During the Pliocene, conglomerates, playa-type deposits and fresh-water carbonate sediments were deposited within closed local basins. The Quaternary sediments with variable thicknesses filled major basins of the northern and southeastern sectors of the study area (Fig. 2).

\section{Methodology}

In order to address the main objectives of this paper, a multidisciplinary approach combining structural, geo- 
logic, geomorphologic, and aeromagnetic data has been performed. All the original and available data were integrated into a Geographic Information System, allowing their spatial analysis.

\subsection{Structural and geomorphic analysis}

Fault traces were mapped in the field and analysed on satellite images with different resolutions ranging from medium to very high (Landsat ETM+, Quickbird and Google Earth) and using digital elevation models (DEM data). Based on the length and significance of the faults, they were classified into principal displacement zones and minor, secondary faults. Shear sense along the faults was inferred in the field from analysis of slickenlines and drag of beds; field measurements were plotted and principal stress directions calculated using the TectonicsFP 1.6.4 software (Reiter and Acs 1996-2011). Also the analysis of strain partitioning for different fault kinematics on longitudinal and oblique fault sets was not an easy task. Identifying the strike-slip component was often only possible on the basis of identifying structures associated with the strike-slip displacement (Konon 2007). In the investigated area, horsetail splays at terminations of the major faults, several rotated blocks in domino style, pull-apart basins and positive flower structures were identified.

The offsets of ridges, alluvial deposits and stream channels allowed the calculation of strike-slip displacements. Slip rate has been obtained from channel offset divided by time (e.g. Noriega et al. 2006). For estimating the slip rates of active faults, the age of the presentday tectonic configuration was considered and then the total cumulative offsets on the active fault planes were calculated. Sediment age in the study area, according to geological maps, is considered as $1.8 \mathrm{Ma}$ (Pleistocene).

\subsection{Interpretation of aeromagnetic data}

The aeromagnetic survey data used in this study are from a total field aeromagnetic survey conducted in 1977 by collaboration between Aero Service Company and the Geological Survey of Iran. These data obtained with a flight height of 500-600 $\mathrm{m}$ and a nominal flight line spacing of $7500 \mathrm{~m}$, were digitized, plotted and interpolated with grid points using the Geosoft program (Oasis Montaj, Version 6.4.2) to produce a total magnetic intensity (TMI) map. The aeromagnetic anomalies in the TMI map range from 39224 to $40148 \mathrm{nT}$ and are characterized by both low and high frequency anomalies. The reduction to the pole (RTP) aeromagnetic data, computed from the grid of TMI data, removes the asymmetry caused by the non-vertical magnetization direction which would have been observed in a magnetic pole (Baranov 1957). This can be a useful aid to interpretation, because asymmetric anomalies become symmetric (Cooper 1997). The reduction operation assumes the total magnetic intensity to be $46531 \mathrm{nT}$, inclination $50.5^{\circ}$ and a declination $3^{\circ}$ according to IGRF (International Geomagnetic Reference Field) in 1975. The acute variations in the magnetic intensity map can indicate variations in either lithology or basement topography. Sedimentary rocks have usually low values of magnetic susceptibility and usually give only an insignificant contribution to the magnetic anomalies (Clark 1997; Gibson and Millegan 1998; Mørk et al. 2002).

The interpretation is that a very high gradient level on an aeromagnetic map usually indicates the difference in magnetic susceptibility such as that between granite (acidic rock), andesite (intermediate rock) and basalt (basic rock); a condition called "intrabasement" (lithology variation). Abrupt variations of anomalies trending on aeromagnetic maps usually indicate vertical discontinuities (faults); a condition called "suprabasement" (basement topography). The shape of the causative body also could be considered by analyzing the contoured anomalies. In case of circular contours and vertical magnetization, the geological body may be interpreted as a volcanic plug. In case of elongated closed contours, the source of magnetic anomalies may be a dyke, whereby the direction of elongation should reflect its strike. In contrast, an elongated steep gradient without a well-defined closure may indicate subsurface faulting and displacement magnetized rocks (e.g. Dobrin 1976).

We have taken several approaches in order to delineate the subsurface structures in the area, which include analytic signal, horizontal gradient and the Euler deconvolution. The analytical signal method is a powerful technique to evaluate buried structures which cause significant linear magnetic anomalies, such as fault zones, steps and dykes. Nabighian $(1972,1974)$ introduced the concept of the analytic signal for magnetic interpretation and showed that its amplitude yields a bell-shaped function over each corner of a 2D body with polygonal cross section. The analytical signal, defined as the anomaly square root of the sum of squares of the horizontal ( $\mathrm{X}$ and $\mathrm{Y}$ ) and vertical derivatives $(Z)$ along the orthogonal axes of the anomaly resolves the anomaly maps.

The horizontal gradient (HG) method is the simplest approach to estimate contact locations of geological bodies in deep areas (e.g. faults). The main advantage of the horizontal gradient method consists in low sensitivity to noise in the data (Phillips 1998). The calculations using the aeromagnetic dataset of TMI-RTP map were presented at an azimuth of $45^{\circ}$.

Euler deconvolution is a method to estimate the depth of subsurface magnetic anomalies (Reid et al. 1990). The Euler method has been applied to the TMI-RTP map, using a moving window of $20 \times 20 \mathrm{~km}$. The Euler 


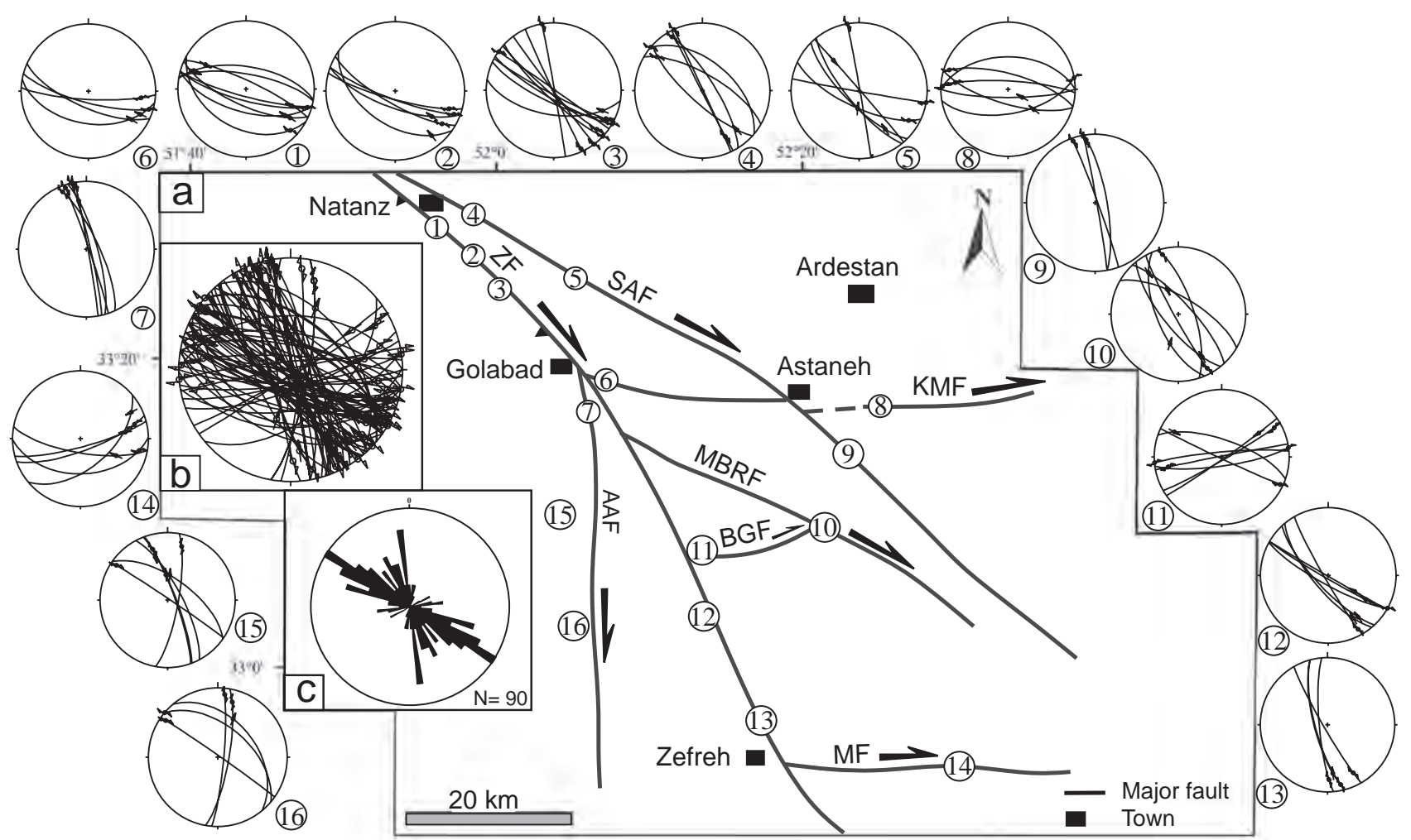

Fig. 3a - Major faults of the study area and horsetail splay structure in the UDMA, with stereoplots of field measurements in the study area. Abbreviations are the same as in Fig. 2. b - Stereoplot (Schmidt net, lower hemisphere projection) showing the fault data collected in the study area. $\mathbf{c}$ - Rose diagram showing the cumulative distribution of the fracture strike data in the rock units.

deconvolution was carried out on the study area using the Standard Euler 3D method of the Geosoft package. The most critical parameter in the Euler deconvolution is the structural index that is introduced as a solution to depth. Three-dimensional Euler solution of the study area for a Structural Index (SI = 1) (Thompson 1982; Reid et al. 1990) is presented. The extension of linear clustering of Euler solutions, given as colored point, clearly defines the solution for depths that range from 1000 to $20000 \mathrm{~m}$.

\section{Results}

\subsection{Fault patterns and structures associated with faults}

In the central part of the UDMA, there are several dominant trends based on the distribution of major and minor faults. The fault pattern consists of major NW-SE trending longitudinal faults that are parallel to the major trend of the Zagros Orogenic Belt, N-S and E-W-trending oblique faults and NE-SW-trending transverse faults (Fig. 2).

These faults cut across sedimentary rocks of Paleozoic age and Cenozoic magmatic rocks and, in places, Pliocene to Quaternary rocks and sediments. Along the faults, horizontal offsets of ridges, alluvial deposits, stream channels, and tectonic structures associated with the strike-slip displacement were observed (Nadimi and Konon 2012).

\subsection{NW-SE-trending faults}

\subsubsection{Zefreh Fault}

The Zefreh Fault (ZF) is located in the southeast termination of Kashan (Qom-Zefreh) Fault zone (Safaei et al. 2008) (Fig. 1). The NW-SE-trending ZF is 130 $\mathrm{km}$ long. The ZF cuts and displaces the UDMA along its whole trace. The fault was identified from north of Natanz town to the south of Zefreh village (Fig. 2). The dextral strike-slip component was recognized based on the analysis of fault lineations, interpretation of Landsat satellite images and displacement of Eocene volcanic and Mesozoic sedimentary rocks. Field data indicate that the fault strikes at $130-160^{\circ}$ and dips $70-85^{\circ}$ to the SW (Diagrams 1-3, 12-13 in Fig. 3). The Zefreh Fault direction abruptly changes to NNW-SSE and several branch faults extend from the major fault to the $\mathrm{S}$ of Golabad village (Fig. 3a). The major branch faults include: Abbas Abad, Kacho Mesqal, Marbin Rangan, Bar Gohar and Marshenan faults. The main fault and branch faults terminate by small- and large-scale horsetail splay structures 

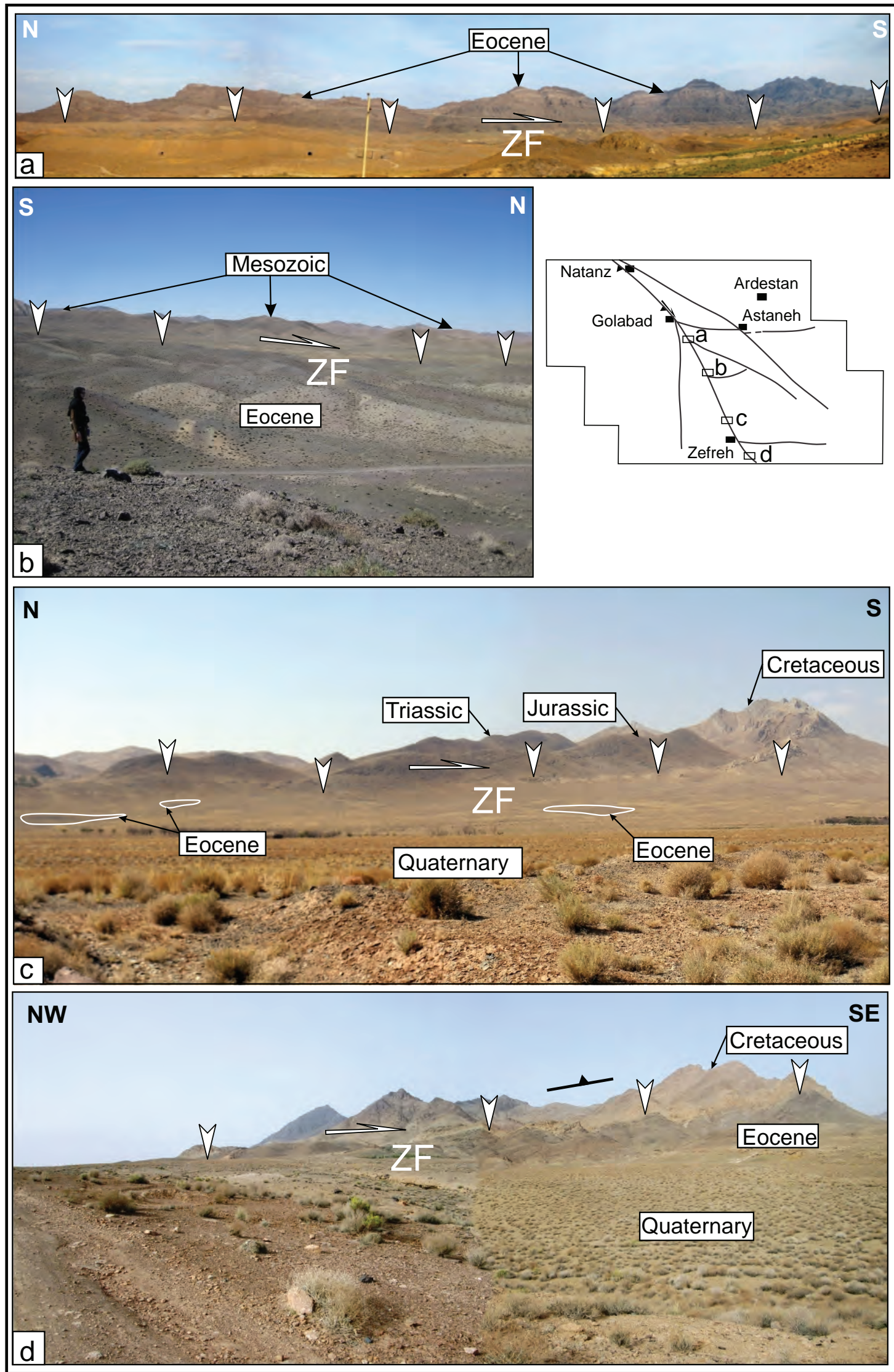

Fig. 4 The trace lines on field images of the Zefreh Fault. Inset: location of the individual photographs. 


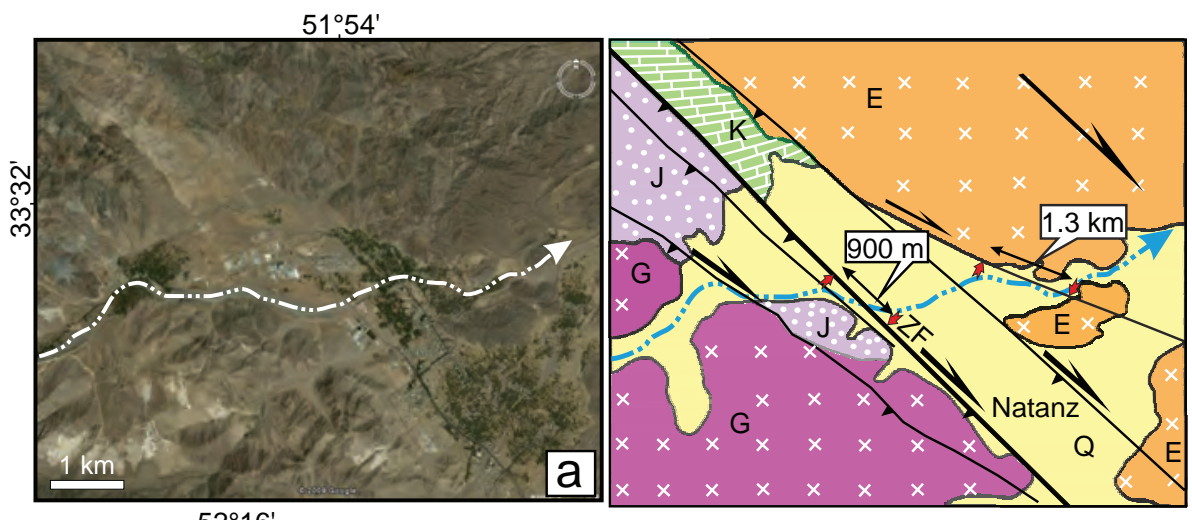

Fig. 5a - Zefreh Fault and its branch faults near Natanz town on Google Earth image and in geologic map. Legend: $\mathrm{J}$ - Jurassic shales and sandstones, $\mathrm{K}$ - Lower Cretaceous limestones and marls, E - Upper Eocene volcanic rocks, $\mathrm{G}$ - Oligocene-Miocene granites, and Q - Quaternary sediments.

b - Zefreh Fault north of the Zefreh village on Google Earth image and in geologic map. Stream (left figure) and alluvial fan (right figure) displaced by the fault. Legend: $\mathrm{T}-$ Triassic dolomites, shales and sandstones, $\mathrm{Q}_{1}^{\mathrm{f}}-$ Pleistocene alluvial fans, $\mathrm{Q}_{1}^{\mathrm{t}}-$ Holocene terraces and $\mathrm{Q}_{2}^{\mathrm{f}}-$ Holocene alluvial fans.
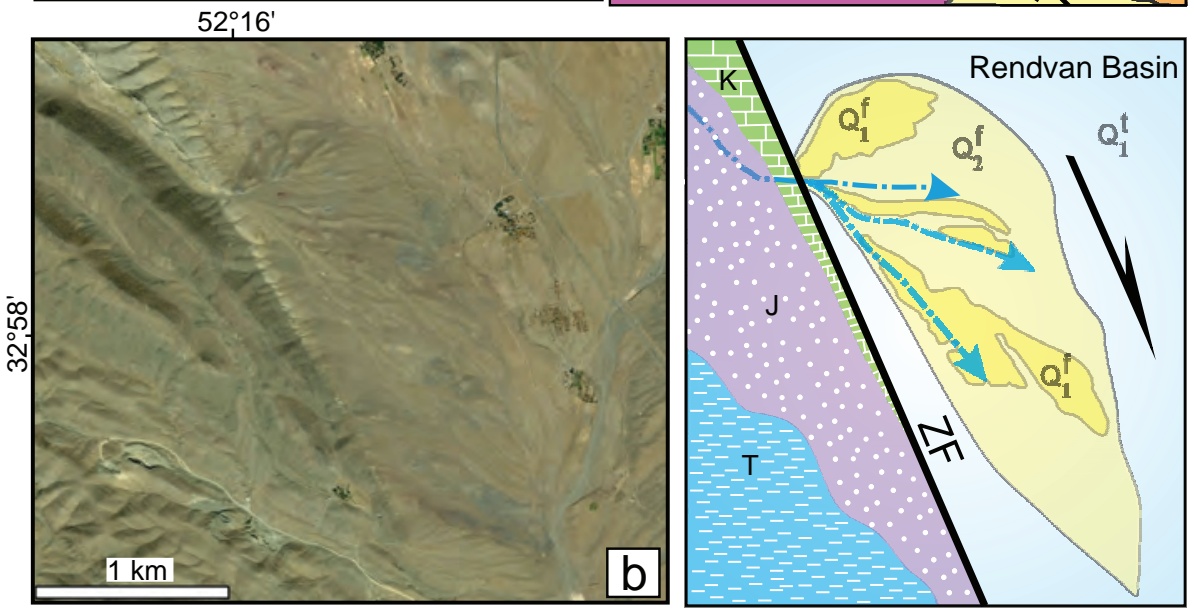

in the study area (Fig. 3a). The stereographic projection of all collected data within the rock units is presented in Fig. 3b. The statistical analysis shows a dominant population oriented towards $130^{\circ}$ (Fig. 3c). The trace of the fault is easily visible as a pronounced line on field imagery, placing Eocene volcanic rocks against Mesozoic sedimentary rocks and Quaternary deposits (Fig. 4). The displacements vary along the fault, the maximum value of dextral displacements of alluvial fan and drainage streams in the northern part of the ZF in the Natanz area were calculated as $\sim 1.3 \mathrm{~km}$ with a slip rate of $\sim 0.72 \mathrm{~mm} / \mathrm{yr}$ (Fig. 5a). Also, an alluvial fan formed in Rendvan Basin in the southern part of the fault to the $\mathrm{N}$ of Zefreh village (the Rendvan Basin is $12 \mathrm{~km}$ long and $2 \mathrm{~km}$ wide and is located along the Zefreh Fault and its branches; Fig. 2). Displacement of drainages has been calculated as $2.6 \mathrm{~km}$ with $\sim 1.4 \mathrm{~mm} / \mathrm{yr}$ slip rate (Fig. 5b). Normal dip-slip and dextral strike-slip components were recognized based on fault slickenline lineations along the faults in Triassic rock units (Fig. 6).
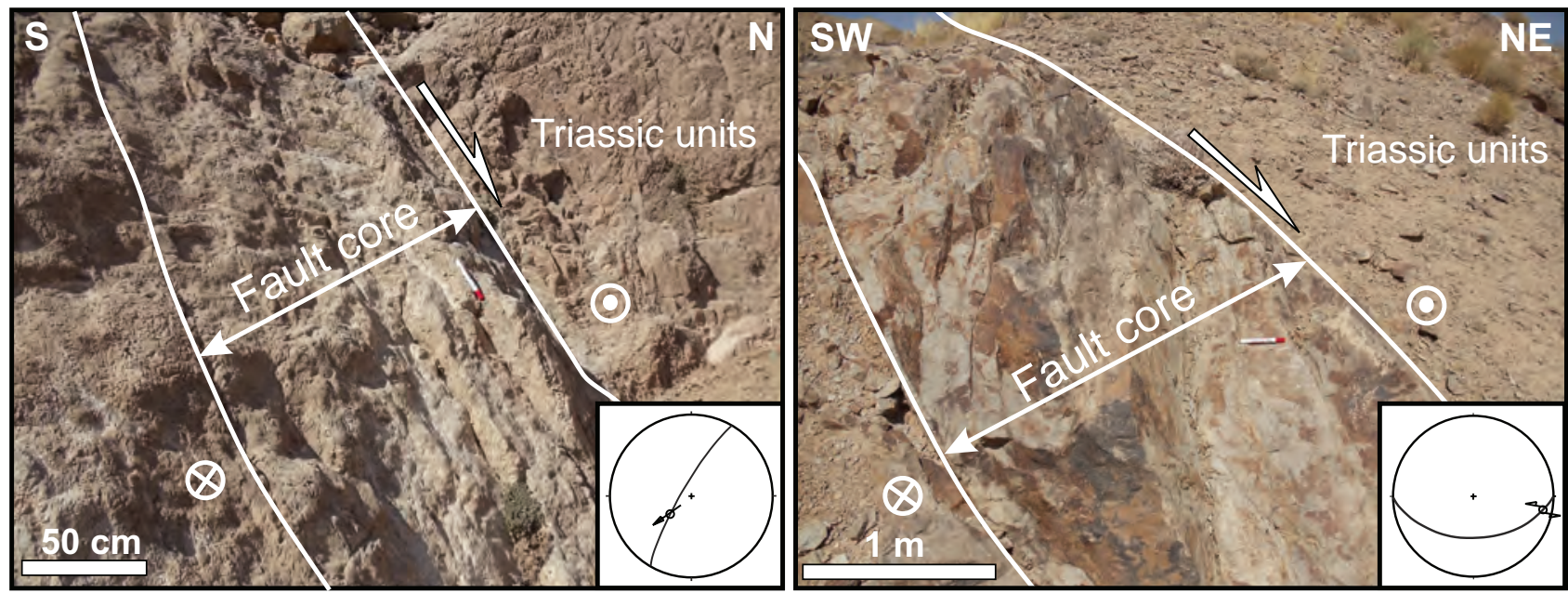

Fig. 6 Slickenlines indicating the normal kinematics along the main fault plane on Triassic units in the Rendvan Basin. 

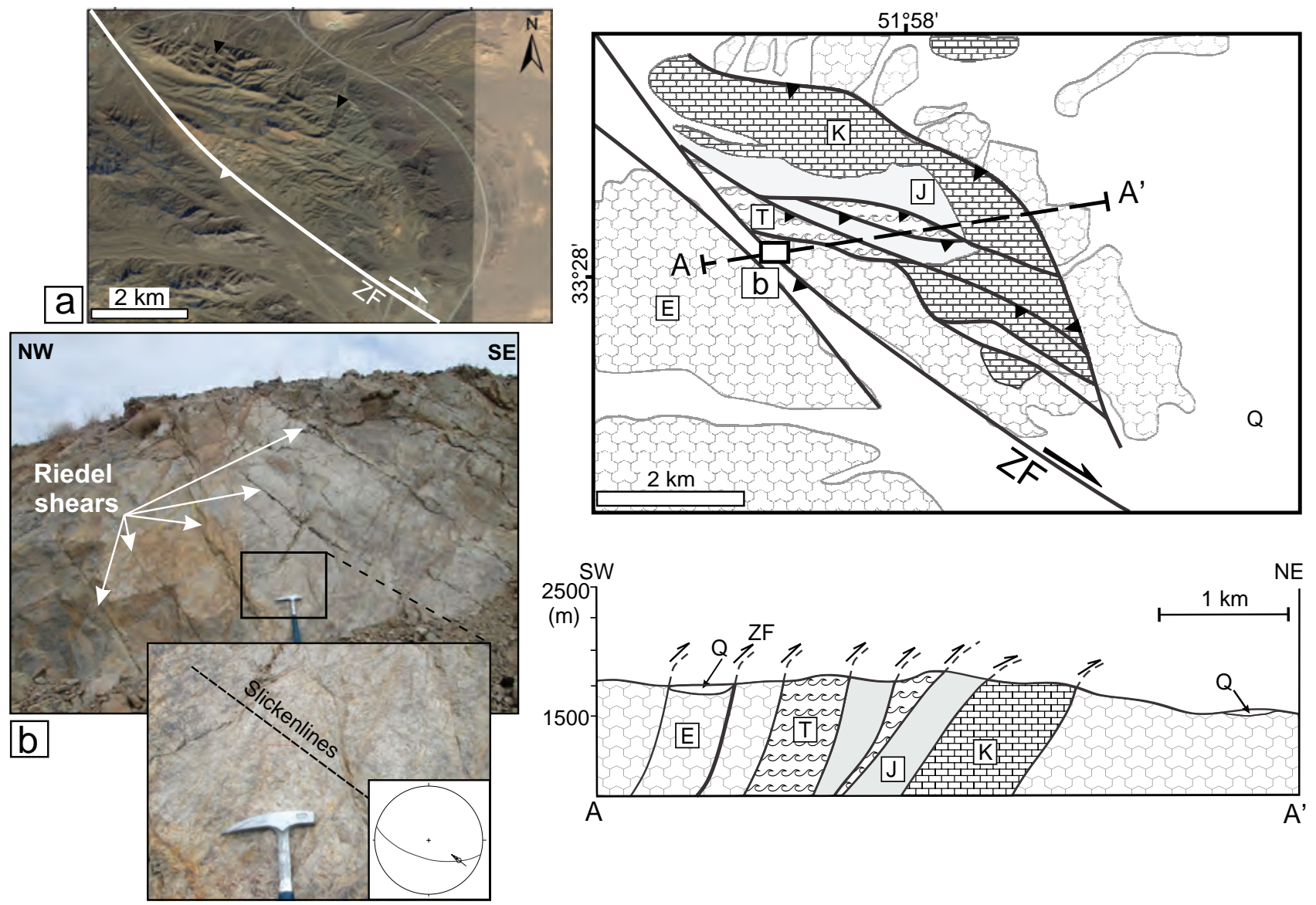

Fig. 7a - Natanz positive flower structure and the geological cross-section through it. Legend: T - Upper Triassic limestones, J - Lower Jurassic shales and sandstones, K - Lower Cretaceous limestones and marls, E - Eocene andesite, Q - Quaternary sediments (geological units based on Zahedi et al. 1978). b - Polished oblique fault surface with horizontal slickenlines within the fault damage zone developed in the Eocene units. Synthetic Riedel shears indicate the dextral kinematics.

Along the fault, evidence for dextral strike-slip transpressional movement was also observed (e.g. positive flower structures of different dimensions). The best examples of these structures are near Natanz town (Fig. 7). The Natanz positive flower structure is located to the S of Natanz, between the Zefreh and branch faults. Mesozoic rock units were here uplifted and thrust onto Cenozoic assemblage. The structure consists of tectonic slices bordered by several NW-SE-trending thrusts and reverse faults. The sense of movements along the Zefreh and branch faults suggests that the structure formed during simultaneous strike-slip and contraction (Fig. 7a-b).

\subsubsection{South Ardestan Fault}

The South Ardestan Fault (SAF) is separated from the Kashan Fault zone north of Natanz town and extends to Nain Basin. The NW-SE-trending SAF is $\sim 120 \mathrm{~km}$ long and it forms the western border of the Ardestan Basin (Fig. 2). Dextral strike-slip component of movement was recognized based on the fault lineations along the fault plane.
Field data and interpretation of the Landsat satellite images indicate that the fault strikes $120-130^{\circ}$ and dips $80-90^{\circ}$ to the SW (Diagrams 4-5, 9 in Fig. 3). In the middle part of the SAF, the main fault exhibits dextral strike-slip kinematics with small reverse component (Fig. 8a-b).

There is a mountain range made up of Eocene magmatic rocks, which is located between the SAF and a branch fault sub-parallel to it. Kinematic indicators and slickensides along the boundary faults show a dextral component of slip. Position of the minor faults with respect to the boundary faults, the dextral strike-slip kinematics and displacement of rock units also indicate a counter-clockwise rotation around vertical axis for the fault-bounded blocks (Fig. 8c).

\subsubsection{Marbin Rangan Fault}

The NW-SE-trending Marbin Rangan Fault (MBRF) is 60 $\mathrm{km}$ long and forms the eastern branch of the Zefreh Fault (Fig. 2). The fault is linear, cuts bedrock along its entire length and has uplifted Late Eocene to Early Miocene gran- 

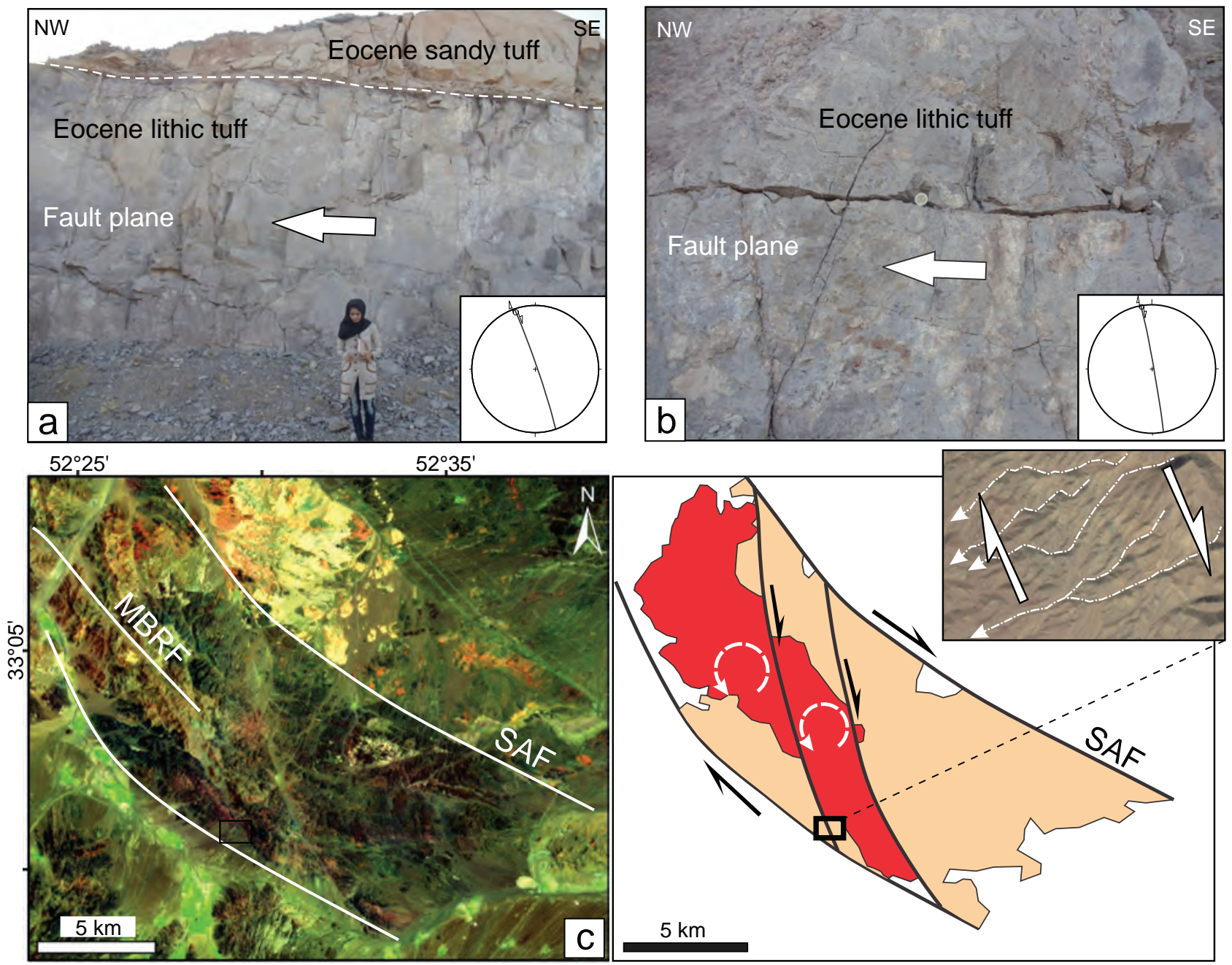

Fig. 8a-b Slickenlines indicating the dextral kinematics along the South Ardestan Fault plane. c - Rotated tectonic blocks are related to strike-slip faults, west of the South Ardestan Fault (SAF). MBRF = Marbin Rangan Fault.

ites and diorites. Dextral strike-slip and reverse components of movements were recognized based on fault lineations along the fault. Field observations indicate that the fault strikes at $320-345^{\circ}$ and dips $70-75^{\circ}$ to the NE (Diagram 10 in Fig. 3). Numerous streams and rivers show evidence for dextral offset along the MBRF. Offset is variable, ranging from $30 \mathrm{~m}$ for minor streams to hundreds of meters for larger drainages (Fig. 9a-b). The largest river has $\sim 600 \mathrm{~m}$ offset (Fig. 9a). The slip rate measured along the fault plane is $\sim 0.33 \mathrm{~mm} / \mathrm{yr}$. The fault zone also cuts Miocene granite and granodiorite units, which indicate dextral strike-slip kinematics inferred from the slickenlines (Fig. 9c-e).

\subsection{E-W-trending faults}

\subsubsection{Kacho Mesqal Fault}

The Kacho Mesqal Fault (KMF) with a length of $75 \mathrm{~km}$ is the longest of the $\mathrm{E}-\mathrm{W}$ oriented fault set. This fault is transpressional with reverse and dextral strike-slip components of movement. The fault is linked to the ZF east of Golabad village and the fault trend changes from $120^{\circ}$ in the western part to $90-95^{\circ}$ near the eastern fault termination (Fig. 2). The fault propagates through mountain areas in the UDMA and extends towards southeast Ardestan. Dextral transpressive faulting was recognized based on slickenlines along the fault plane (Diagrams 6 and 8 in Fig. 3 and Fig. 10a). The KMF cuts Eocene andesite rocks in the $\mathrm{W}$ and juxtaposes Miocene andesitic lavas with Eocene andesites near the Astaneh village. To the $\mathrm{E}$ of Astaneh village, the fault passes an alluvial plain and forms the boundary between andesite rock units and the plain in the Kacho Mesqal village.

\subsubsection{Bar Gohar Fault}

The E-W-trending Bar Gohar Fault (GBF), with 20 km length, has a curved shape. The fault trend changes from 

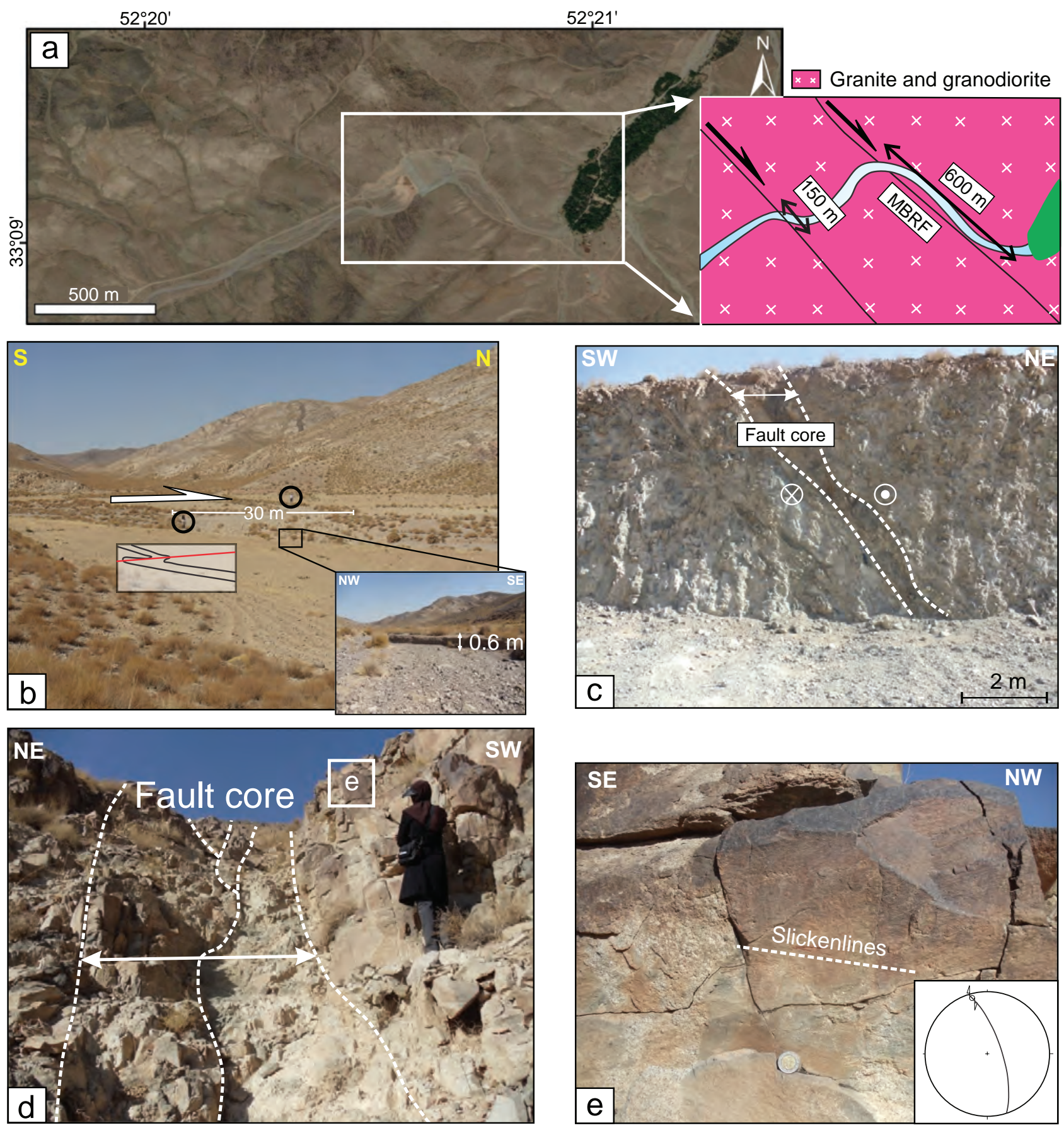

Fig. 9a - Dextral offset of stream along the Marbin Rangan Fault. b - Field photo of stream displacements observed at the Marbin Rangan Fault. c - The trace of Marbin Rangan Fault (bright dashed line). d - Marbin Rangan Fault crushed zone in Miocene granites to the east of the Marbin Rangan village. e - Slickenlines indicating the dextral kinematics along the main fault plane.

$80-90^{\circ}$ in the western part to $75^{\circ}$ near its eastern termination (Fig. 2). The western extremity of the fault is linked to the ZF. Dextral components were recognized based on slickenlines (Diagram 11 in Figs 3 and 10b-d). Bar Gohar
Fault exposed Upper Eocene dacite and rhyodacite. The fault cuts through Miocene granites and granodiorites in the Bar Gohar village and finally reaches the MBRF (Fig. 2). 

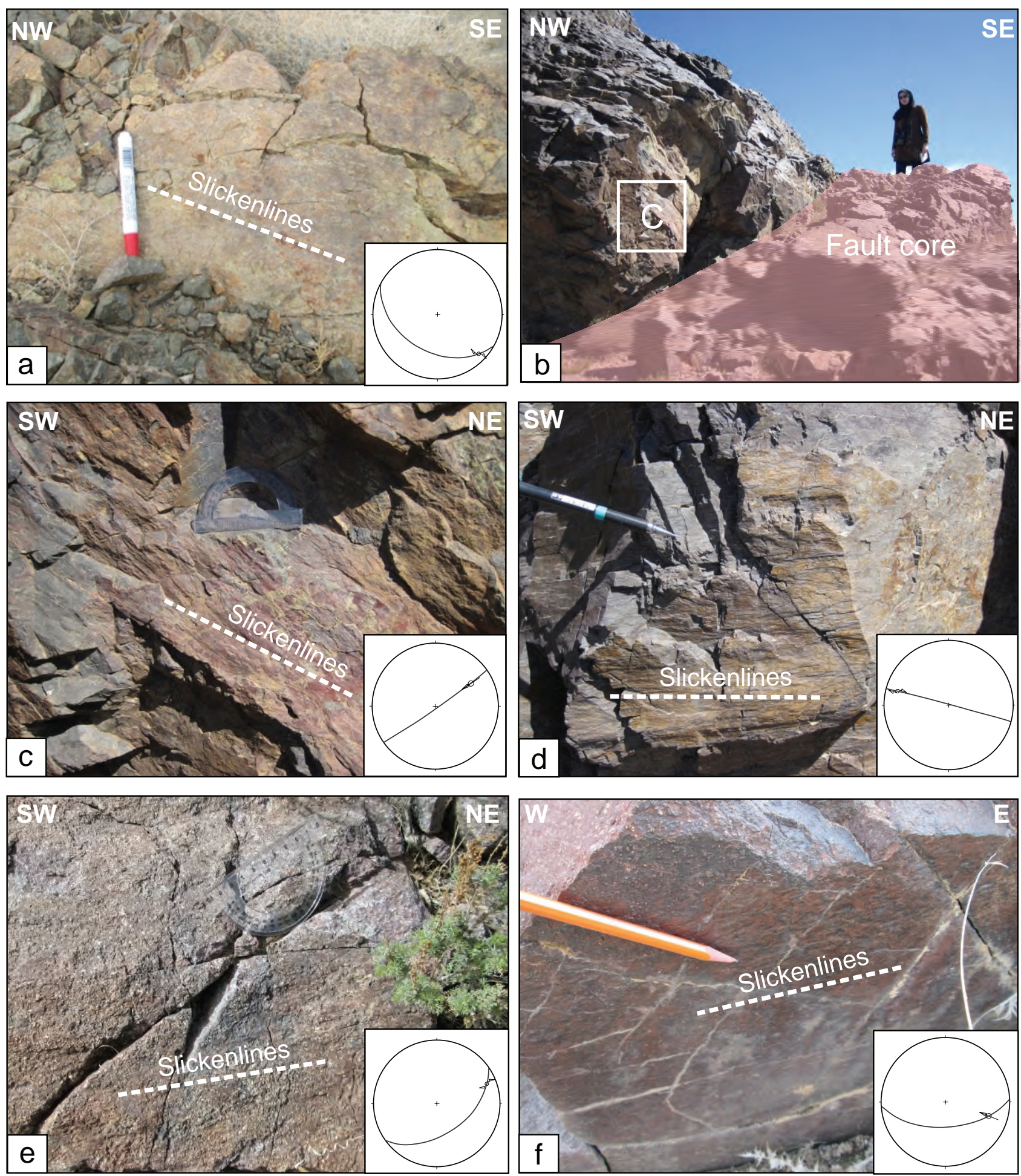

Fig. 10a - Slickenlines indicating the dextral kinematics along the Kacho Mesqal Fault plane. b-d - Slickenlines indicating the dextral kinematics along the Bar-Gohar Fault plane. e-f -The polished Marshenan Fault surface shown with its slickenlines.

\subsubsection{Marshenan Fault}

The 45 km-long, E-W-trending Marshenan Fault is linked to the ZF near its western termination. Field data and interpretation of the Landsat satellite images indicate that the fault strikes at $90-105^{\circ}$ and dips $40-50^{\circ}$ to the SSW (Fig. 2). Dextral strike-slip and normal components of movements were identified from slickenline lineations (Diagram 14 in Fig. 3 and Fig. 10e-f). 

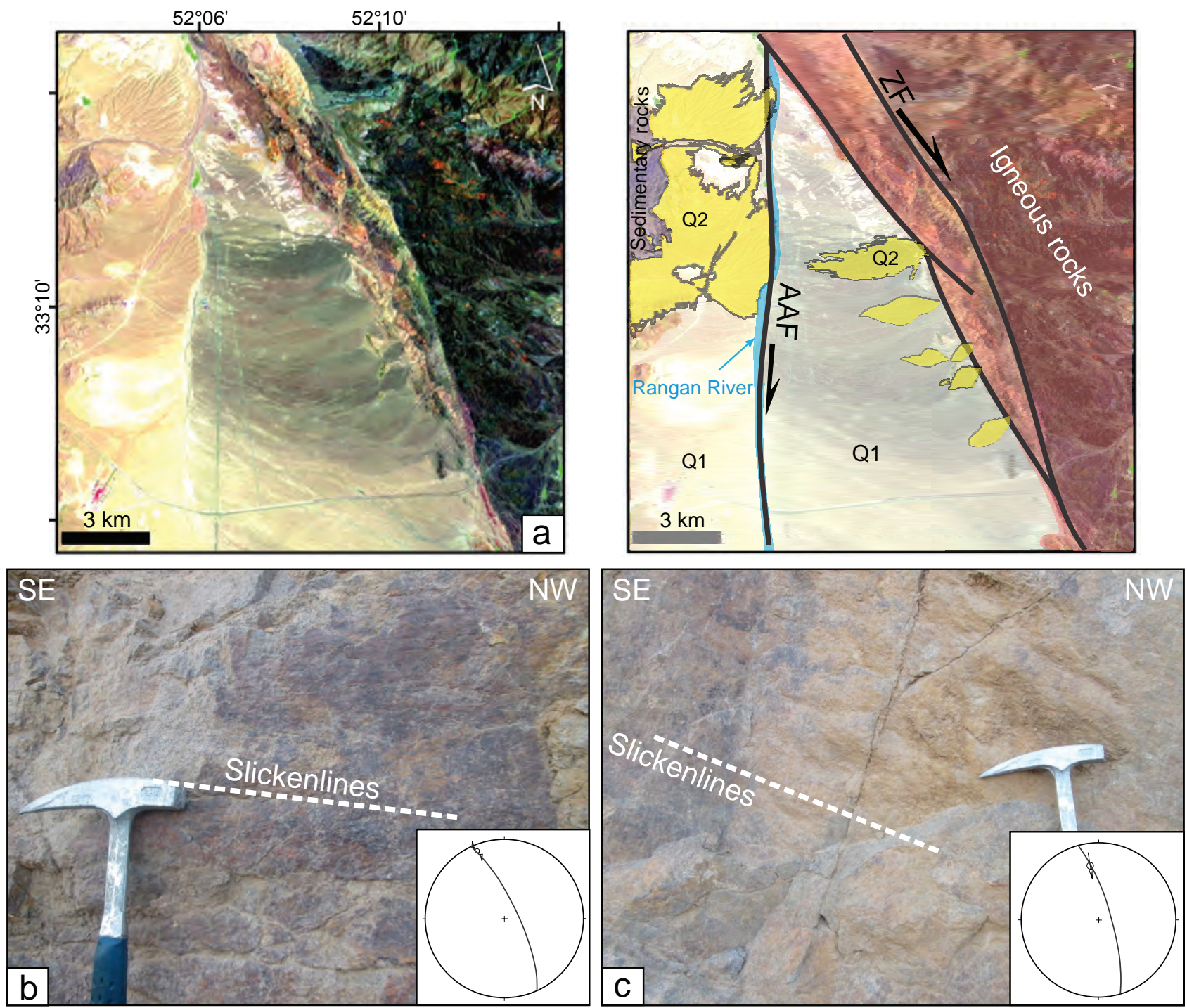

Fig. 11a - Landsat satellite image of a part of the study area indicating the trace of the Abbas Abad Fault and the Rangan River. Legend: Q1 Pleistocene alluvial fans, Q2 - Holocene terraces, and Holocene alluvial fans. b-c - Slickenlines indicating the dextral kinematics along the Abbas Abad Fault plane.

\subsection{NNW-SSE trending faults}

\subsubsection{Abbas Abad Fault}

The NNW-SSE-trending Abbas Abad Fault is $60 \mathrm{~km}$ long, and forms the western border of the Abbas Abad Basin (Fig. 2). The northern termination of the fault joins the ZF. Dextral strike-slip and normal dip-slip components were recognized based on analysis of fault slickenlines. Field data and interpretation of the Landsat satellite images indicate that the fault strikes at $345-360^{\circ}$ and dips $75-80^{\circ}$ to the ENE (Diagrams 7, 15-16 in Fig. 3 and Fig. 11b-c). The middle part of AAF with $22 \mathrm{~km}$ length is covered by Quaternary alluvial deposits (Fig. 2). Extensional conditions in this part could have had an important role in the formation and evolution of the Abbas Abad Basin. The Abbas Abad Basin is $20 \mathrm{~km}$ long and $10 \mathrm{~km}$ wide with its axis elongated in the NNW-SSE direction. The basin becomes wider from north to south and is controlled by active dextral strike-slip faults. The basin is a typical wedge-shaped depression extended between the Zefreh and Abbas Abad faults. The lowest elevation of the basin is at $2000 \mathrm{~m}$ above sea level, whereas volcanic mountain ridges at its eastern and sedimentary mountain ridges at the western margin reach elevations of 2500 and $2200 \mathrm{~m}$, respectively (Fig. 2). Several Quaternary alluvial fans developed towards the Abbas Abad Basin. The fault trace is visible as a pronounced lineation on Landsat ETM+ imagery along the Rangan River. Quaternary alluvial fans have been sharply truncated along the fault (Fig. 11a). 


\section{Analysis of aeromagnetic data and filtered magnetic maps}

\subsection{TMI-RTP map}

The TMI map (Fig. 12a), in the study area shows one large dominant magnetic anomaly. This is an elongated feature with NW-SE orientation located in the central part of the study area, having a strike of $300-330^{\circ}$ and a length of more than $120 \mathrm{~km}$. It was interpreted as a major fault because its boundaries are sharply terminated, and it coincides with the Zefreh Fault. The TMI map clearly reflects the basic geology of the study area.

The RTP is a filtering technique used to align the peaks and gradients of magnetic anomalies directly over their sources. The TMI-RTP map (Fig. 12b) shows that due to elimination of the inclination and their declination of the magnetic field at this area, the anomalies become larger and they center over their respective causative bodies to some extent. In addition, the magnetic gradients are rendered more intense and steeper, the anomalies reliefs increase, giving rise to a higher resolution in the lithologic and structural inferences encountered. Several zones with high and low magnetic values are present, the magnetic highs being separated from magnetic lows by steep gradients. The elongations of magnetic anomalies at the center of the area indicate that it is structurally controlled by a fault with a major axis in the NW-SE direction.

\subsection{Analytic signal}

Figure 13 with analytical signal map of the study region reflects similar trends observed in total magnetic intensity map, which suggests that the magnetic basement occurs at a shallow depth. The trends apparent from the analytic signal (amplitudes) are shown in Fig. 13, which shows broadly two magnetic high trends running NW-SE and NE-SW and some minor trends like N-S and $\mathrm{E}-\mathrm{W}$.

\subsection{Horizontal gradient}

The horizontal gradient map shows major anomalies in NW-SE directions (Fig. 14a). These correspond to a structural complexity determined by faults within the basement that are shown by contact zone with a large magnetic susceptibility difference.

\subsection{Euler deconvolution}

The Euler solution map has deep contacts in the study area (Fig. 14b). Most of the Euler solutions in the east-

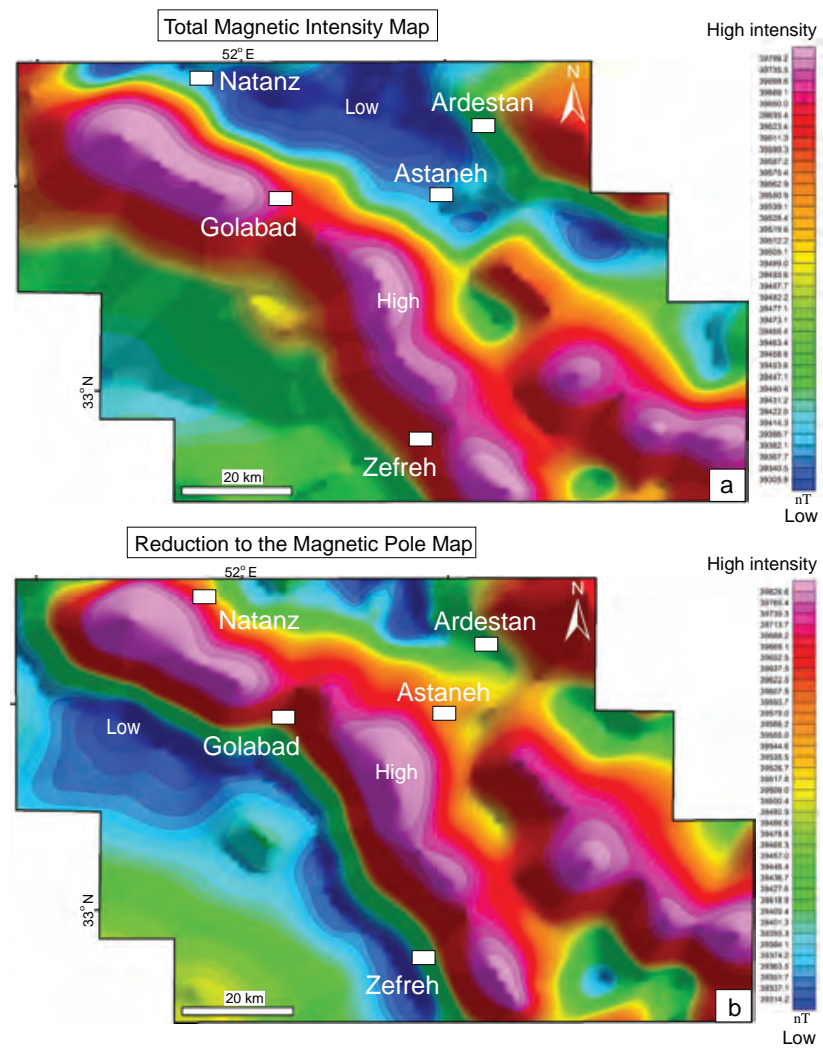

Fig. 12 Total magnetic intensity map of the study area (a) reduced to the magnetic pole map (b).

ern part show a rather shallow depth of c. 1000-4000 $\mathrm{m}$. The deep areas in the $\mathrm{W}$ part of the area are not uniform. In the NW part, the solutions are situated at a high depth of c. 6000 to $10000 \mathrm{~m}$, and in the SW part the solutions are situated at a shallow depth with an increasing depth trend. In the center of the area, Euler plots also show non-uniform depth distribution from shallow to high depths. The average depth for the main trend in the study area (NW-SE) was estimated at $\sim 8 \mathrm{~km}$.

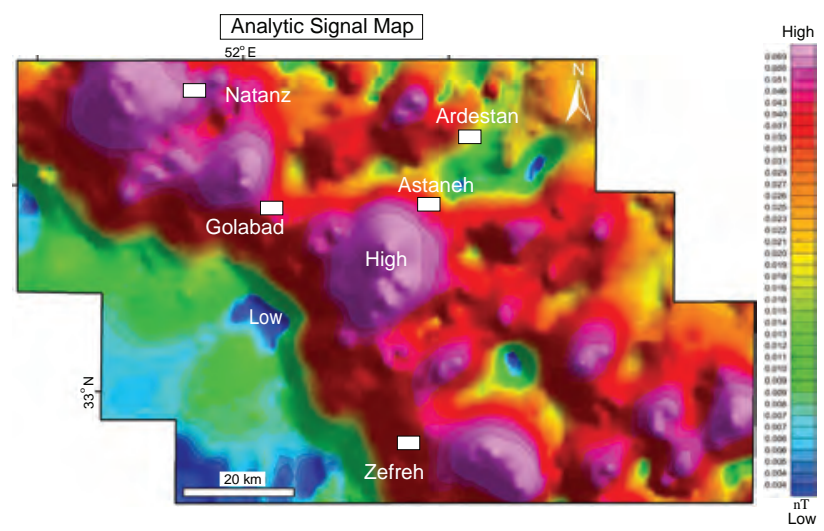

Fig. 13 Analytic signal map of the study area. 

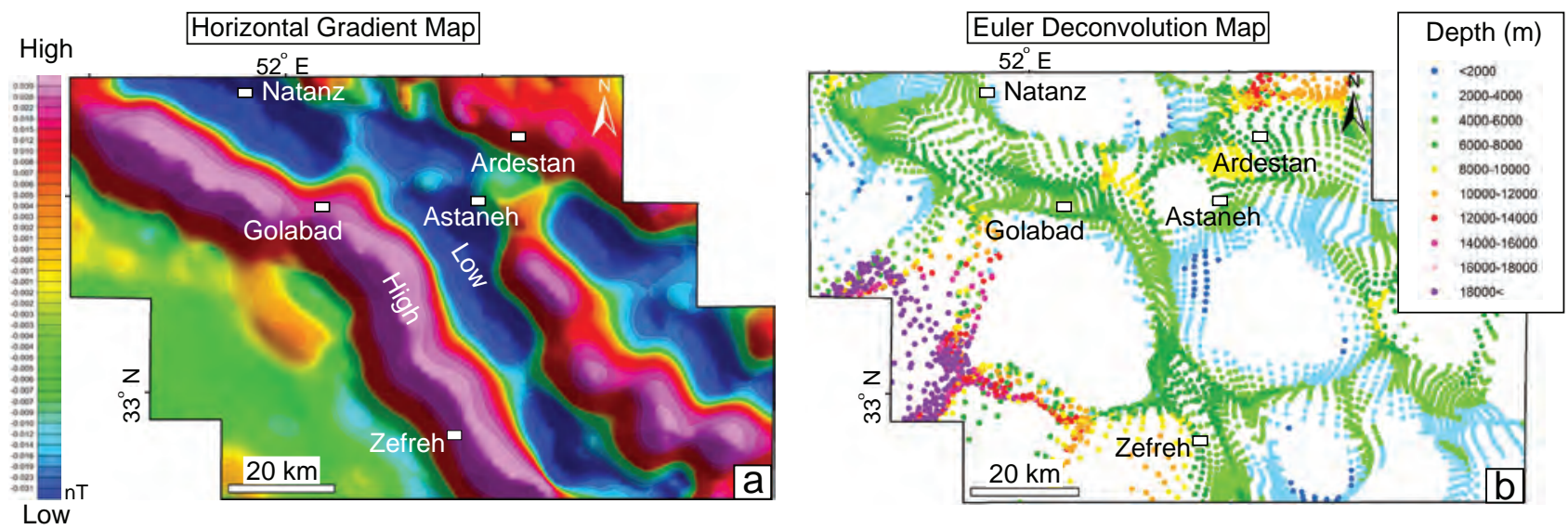

Fig. 14a - Horizontal gradient of Total magnetic intensity-Reduction to the pole (TMI-RTP) map at azimuth $45^{\circ}$. $\mathbf{b}-$ Euler solution map for the structural index (1.0) and maximum relative error of $15 \%$.

\section{Seismicity}

The analysis of seismicity in Iran reveals that large earthquakes (>Mw 6.5) usually occur in the northern part of the country, while low-magnitude seismicity is prevalent in Zagros, suggesting that most of the strain in this area is aseismic (Masson et al. 2007). Distribution of both historically and instrumentally recorded earthquakes indicates that the Ardestan region is a seismically active tectonic zone, but with low-magnitude seismicity $(<\mathrm{Mw} 5$; data from 1963 to 2015). An analysis of earthquake focal mechanisms (for $>\mathrm{Mw}$ 5) reveals dextral-oblique thrusting along the $\mathrm{N}$ termination of Kashan Fault zone (Babaahmadi et al. 2010; Allen et al. 2011).

Most of the seismic activity is located in the western part of the area. A significant seismic activity around the $\mathrm{N}$ and $\mathrm{S}$ termination of the ZF was observed. The earliest recorded earthquake in this region dates back to year 1344, which took place near the southern tip of the fault (Ambraseys and Melville 1982; Fig. 15).

In order to determine the geometry of ZF at depth, we plotted three different cross-sections perpendicular to the major tectonic structures in this area. The depths of these 627 events range from 1 to $36 \mathrm{~km}$. Cross-section in the northern part of the ZF shows the earthquakes to have a depth of $30 \mathrm{~km}$. The central and southern parts of the ZF have less than $15 \mathrm{~km}$ depth (Fig. 15).

\section{Discussion}

\subsection{Zefreh Fault as a basement fault}

Figure 16a shows two sets of contact locations resulting from the analysis of the aeromagnetic map filtered by horizontal gradient and analytical signal methods (here combined as a color composite image). Dark points denote estimated locations of contacts according to the horizontal gradient method in the subsurface, and light points show the estimated locations of contacts according to the analytical signal method at surface or very shallow depth. The extracted lineaments in Fig. 2 and inferred aeromagnetic lineaments in Fig. 16a were investigated and the main lineament was observed in the study area, with the major orientations of the lineament sets in NW-SE and minor sets in NE-SW and E-W directions. General coincidence of lineament trends was observed in the study area which means that these lineaments reflect real continuous fractures in depth (Fig. 16b).

The NW-SE set of fractures are present in central part of the study area. This set is interpreted as transpressional fractures as they parallel faults like Zefreh and South Ardestan, which cross the study area in a NW-SE direction with more than $100 \mathrm{~km}$ length (Fig. 16a). In addition to the main fault, some of its branches can be considered as basement faults. Several faults inferred from aeromagnetic anomalies turn to a NE-SW direction. This set is interpreted as transtensional fractures. Some other minor lineaments are the $\mathrm{N}-\mathrm{S}$ and $\mathrm{E}-\mathrm{W}$ sets that accommodated dextral strike-slip movement.

Based on the above, the Zefreh Fault can be considered as one of the major tectonic structures in the study area, whose effects continue from surface to the basement. The anomalies map clearly reflects the igneous rock units of the UDMA that were interpreted as major faults because their boundaries are sharply terminated, and coincide with the Zefreh Fault. The analytic signal filtering and field observations helped to identify fault orientations at shallow depths. The horizontal gradient filters and earthquake data has allowed us to reveal the structural complexity of the area with faults at greater depths within the basement. According to the Euler deconvolution method (Fig. 14b), the Zefreh Fault shows different depths from 6000 to $8000 \mathrm{~m}$. The data obtained from earthquakes also show different depths along the Zefreh Fault. According to the trends identified of surface 

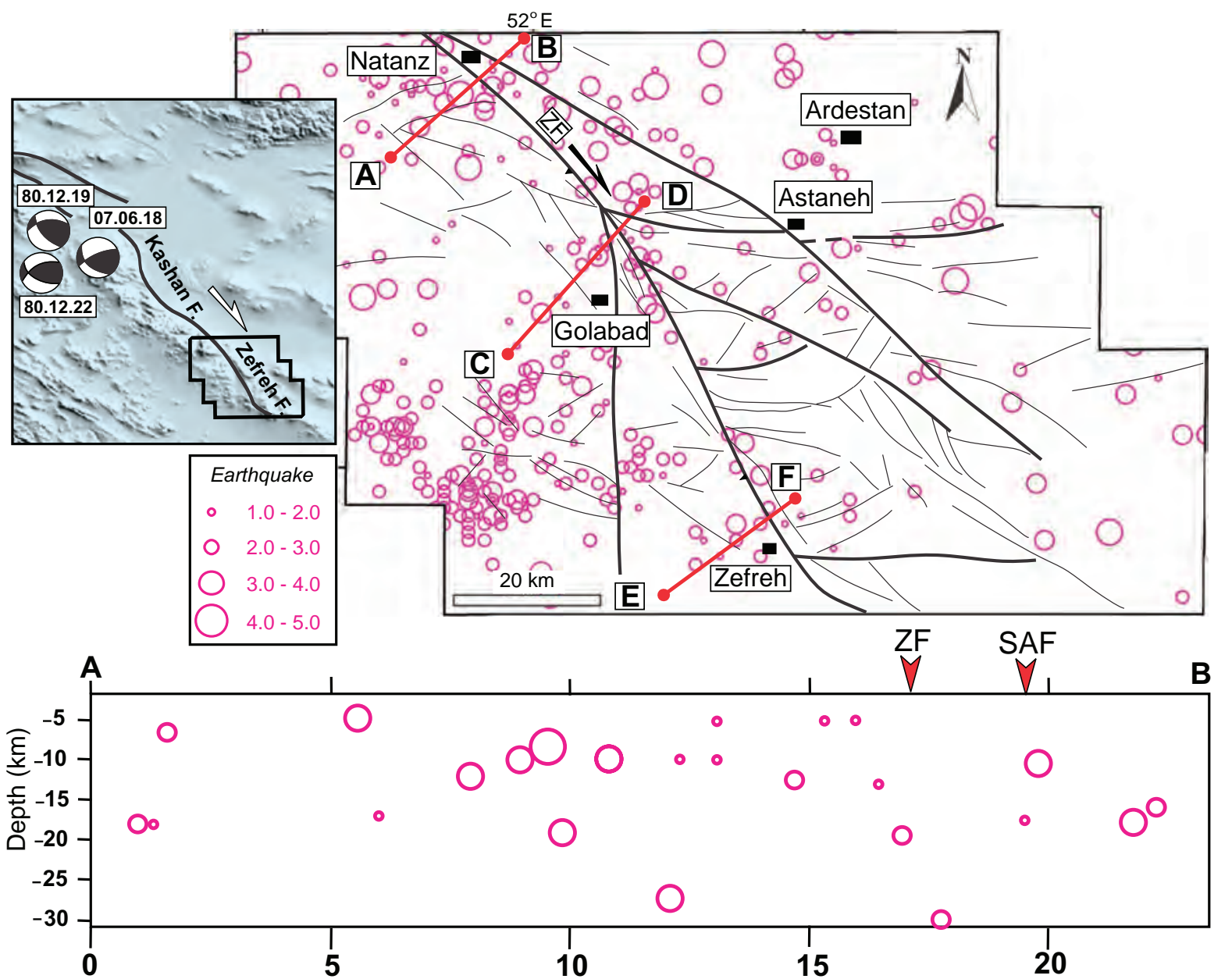

$52^{\circ} \mathrm{E}$

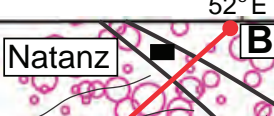

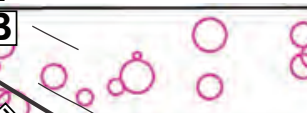
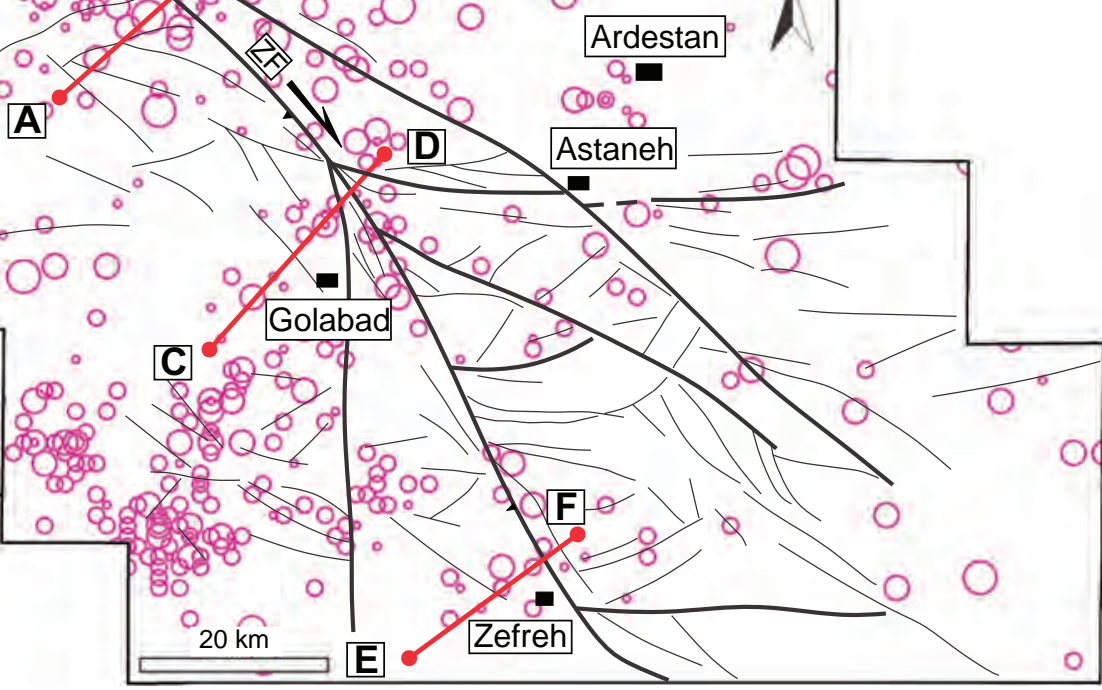

15
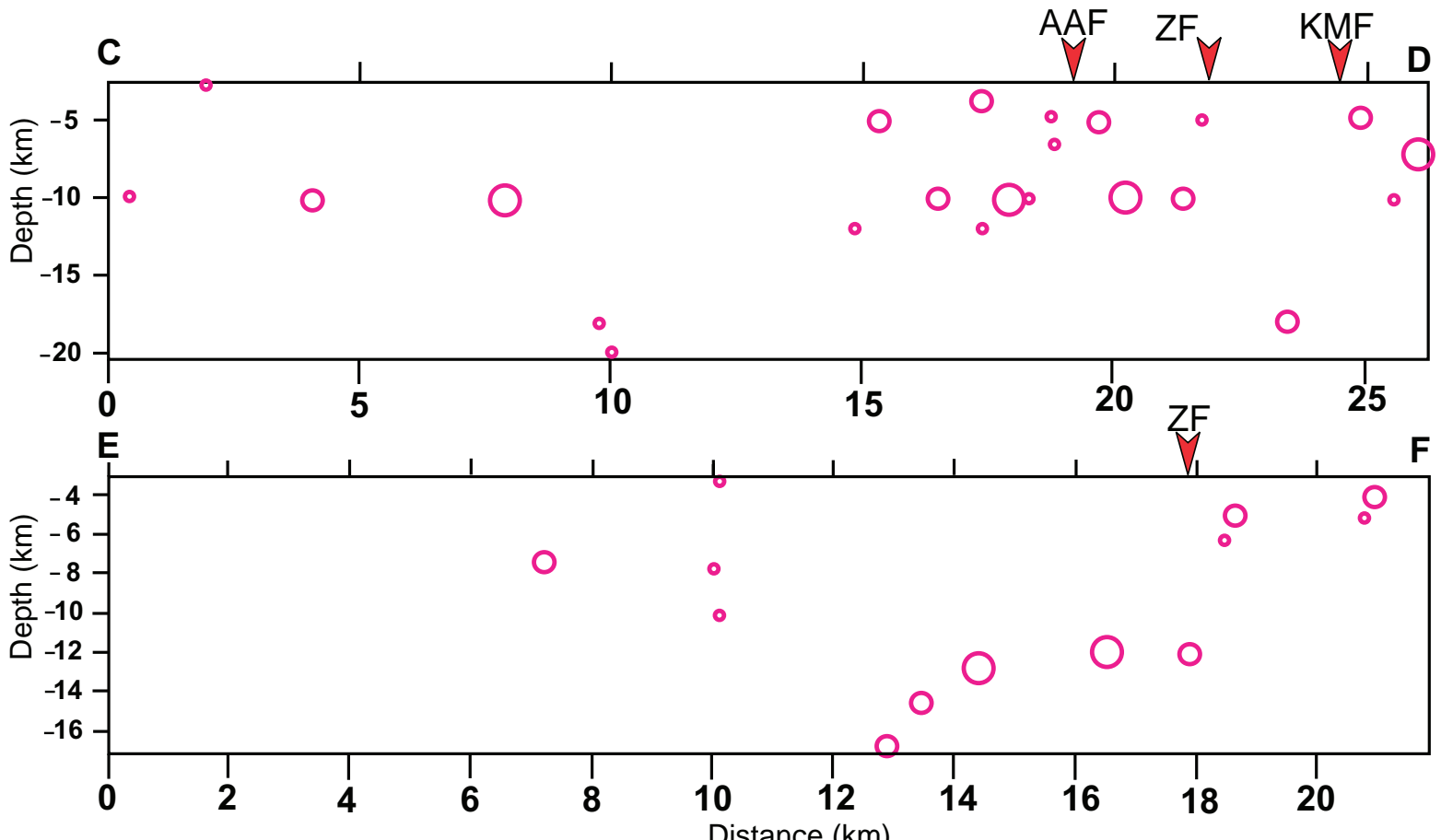

Fig. 15 The distribution of earthquake epicenters around the study area (Iranian Seismological Center Online Databank, http://irsc.ut.ac.ir). The data used here were recorded from 1963 to 2015. Cross-section across the Zefreh Fault (A-B: northern, C-D: central and E-F: southern parts). 

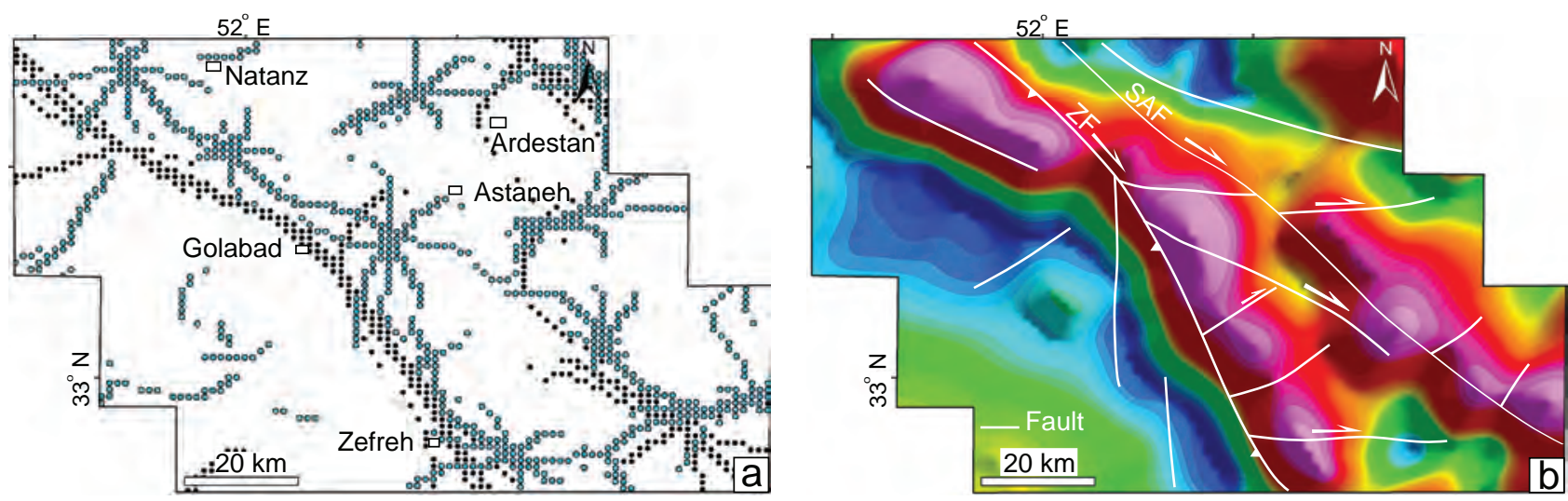

Fig. 16a - Estimated locations of contacts according to the horizontal gradient method (dark) and analytical signal method (light). $\mathbf{b}-$ Total magnetic intensity-Reduction to the pole map (TMI-RTP) and the effect of lineaments observed in basement.

and subsurface data (Fig. 16a), the Zefreh Fault has also variable dip at depth.

\subsection{Strike-slip faulting in the Arabia-Eurasia collision zone}

Prior to the Miocene, the Arabian Plate interacted with the Iranian lithospheric block along the Main Zagros thrust. According to the reconstruction by McQuarrie et al. (2003) and based on calculations of relative plate motions and crustal shortening, the direction of ArabiaEurasia convergence changed from NE-SW since $56 \mathrm{Ma}$ (late Paleocene) to $\mathrm{N}-\mathrm{S}$, obliquely to the Zagros Orogenic Belt, about $19 \mathrm{Ma}$ ago (early Miocene). During the change in convergence direction, strike-slip movements were initiated and reverse faults and thrusts changed to oblique reverse-dextral strike-slip faults.

There are several patterns of deformation associated with strike-slip faulting during the plate convergence in the continental interior (see Allen et al. 2011). Basement blocks can rotate about vertical axis to accommodate $\mathrm{N}-\mathrm{S}$ shortening and arc-parallel lengthening, as proposed for the Zagros (Talebian and Jackson 2004). Alternatively, they can accommodate relative motion between non rotating blocks such as between Central and Eastern Iran (e.g. Dehshir and Anar faults; Meyer and Le Dortz 2007).

\subsection{Tectonic evolution of the central part of the UDMA}

Post-magmatic tectonic evolution of the central part of the UDMA is interpreted here as having involved two main stages.

(1) First stage was the formation of major NW-SE to NNW-SSE-trending reverse and thrust faults during shortening and exhumation of older rocks in the UDMA and adjacent areas. These structures developed as a result of convergence between the Eurasian and Arabian plates. The best examples of these contractional structures are shown in Figs 2, 4, 5b and 7.

This stage is correlated with final convergence and onset of collision of the Arabian and Eurasian plates after Eocene-Oligocene. Crustal thickening and thrusting of numerous tectonic slices are the main phenomena that have formed at this shortening stage (e.g. Paul et al. 2006; Nadimi and Konon 2012; Nadimi 2015) and Central Basin (Morley et al. 2009). Paul et al. (2006) suggested that the structures in the SSZ developed not only in result of thin-skinned tectonics but also from thick-skinned tectonics affecting the basement of the zone. Gravity and seismological data point to the occurrence of a crustal-scale fault connected with the Main Zagros Thrust. During this event, the oldest rock units were also exhumed to shallower crustal levels as a consequence of thrust movements (e.g. Vernant et al. 2004; Paul et al. 2006). Morley et al (2009) suggested that the Central Basin, Zagros and Alborz Mountains all indicate this widespread crustal shortening and that uplift of the Central Basin from approximately sea level to $900-1000 \mathrm{~m}$ occurred during the middle or late Miocene, after deposition of the marine Qom Fm.

(2) From the beginning of late Pliocene to Quaternary, a change in the convergence of the Arabian and Eurasian plates resulted in fault reactivation and strikeslip faulting. Sedimentary basins, horsetail splays, rotated blocks and flower structures are the main observed structures of this stage. Positive flower structures of different scales (SE Natanz) formed during this deformation. The dextral transpressional deformation is interpreted to form a linked system of anastomosing NW-SE-trending faults. Transpressional deformation also formed thrusts with $\mathrm{E}-\mathrm{W}$ to WNW-ESE orientations and dextral offsets on NW-SE to NNW-SSE- 
trending faults (Figs 4, 9). The deformation correlates with N-S to NNE-SSW-oriented maximum horizontal stress direction. This late deformation also affected Quaternary deposits and alluvial fans.

\section{Conclusions}

Satellite images, digital elevation models and surface field observations imply that in the $\mathrm{W}$ part of the Central Iran, fault patterns consist of major NW-SE, NE-SW, $\mathrm{N}-\mathrm{S}$ and $\mathrm{E}-\mathrm{W}$ trends. The Zefreh Fault is the major identified lineament in the study area with a NW-SE direction and a major dextral transpressional kinematics. Several branch faults originated in the UDMA from the Zefreh Fault.

1) The dextral transpression also formed horsetail splay structures at the southeastern termination of the Zefreh Fault, rotated blocks (domino style) of different sizes and with contrasting sense of rotation about vertical axis, positive flower structures in the southeast of Natanz town and sedimentary basins in southern part of the study area.

2) The interpretation of the aeromagnetic map in the study area and application of selected filtering methods to the aeromagnetic data confirmed the Zefreh Fault as the major tectonic lineament affecting the basement in the study area.

3) The presence and distribution of earthquakes indicates that this part of UDMA is still tectonically active. Dissecting of Quaternary deposits and offsets of drainages and rivers confirms the activity of the faults during Quaternary time.

Tectonic evolution of the study area is generally interpreted in terms of two main stages: (1) a contractional stage involving formation of major thrusts during shortening and exhumation of the older rocks in the UDMA and adjacent areas after Eocene-Oligocene, and (2) a transpressional stage, resulting from a change in shortening direction during the Arabian-Eurasian Plate convergence after Pliocene. The latter stage is recorded by strike-slip movements along faults in the study area.

Acknowledgements. Our special words of thanks go to the people whose guidance and assistance were indispensable in the successful completion of this study. This paper was supported by University of Isfahan, Iran. We would like to express our appreciation towards Dr. Caroline M. Burberry, University of Nebraska-Lincoln, USA and an anonymous reviewer for their remarkable suggestions and comments. We are also particularly grateful to Nasim Saddi for carefully checking the English and linguistic improvements.

\section{References}

Agard P, Omrani J, Jolivet L, Mouthereau F (2005) Convergence history across Zagros (Iran): constraints from collisional and earlier deformation. Int J Earth Sci 94: 401-419

Agard P, Omrani J, Jolivet L, Whitechurch H, Vrielynck B, Spakman W, Monie P, Meyer B, Wortel R (2011) Zagros Orogeny: a subduction-dominated process. Geol Mag 692-725

Aghanabati A (2004) Geology of Iran. Geological Survey of Iran Publications, Tehran, pp 1-582

Alavi M, MahdaVi A (1994) Stratigraphy and structure of the Nahavand region in western Iran and their implications for the Zagros tectonics. Geol Mag 131: 43-47

Allen MB, Jackson J, Walker R (2004) Late Cenozoic reorganization of the Arabia-Eurasia collision and the comparison of short-term and long-term deformation rates. Tectonics 23: 1-16

Allen MB, Kheirkhah M, Emami MH, Jones SJ (2011) Right-lateral shear across Iran and kinematic change in the Arabia-Eurasia collision zone. Geophys J Int 184: 555-574

Ambraseys NN, Melville CP (1982) A History of Persian Earthquakes. Cambridge Earth Science Series, Cambridge University Press, Cambridge, pp 1-212

Babaahmadi A, Safaei H, Yassaghi A, VafaH, Naeimi A, Madanipour M, AHMAdi M (2010) A study of Quaternary structures in the Qom region, west Central Iran. J Geodyn 50: 355-367

BARANOV V (1957) A new method for interpretation of aeromagnetic maps: pseudo-gravimetric anomalies. Geophysics 22: 359-383

Berberian F, Berberian M (1981) Tectono-Plutonic Episodes in Iran. Geological Survey of Iran, Report 52: 566-593

Berberian M, King GCP (1981) Towards a paleogeography and tectonic evolution of Iran. Can J Earth Sci 18: 210-265

Berberian F, Muir ID, Pankhurst RJ, Berberian M (1982) Late Cretaceous and early Miocene Andean-type plutonic activity in northern Makran and central Iran. J Geol Soc, London 139: 605-614

Clark DA (1997) Magnetic petrophysics and magnetic petrology, aids to geological interpretation of magnetic surveys: AGSO J Aust Geol Geophys 17: 83-103

Cooper RJ (1997) GravMap and PFproc: software for filtering geophysical map data. Comput and Geosci 23: 91-101

Dobrin MB (1976) Introduction to Geophysical Prospecting. McGraw-Hill, New York, pp 1-630

EмAмі MH (2000) Magmatism in Iran. Geological Survey of Iran, Tehran, pp 1-622

FARHOUd G (1978) A comparison of Zagros geology to island arcs. J Geol 86: 323-34 
Gibson RI, Millegan PS (1998) Geologic Applications of Gravity and Magnetics: Case Histories. Society of Exploration Geophysicists, Tulsa, OK, USA, pp 1-171, doi: 10.1190/1.9781560801832

Haghipour A, Aghanabati A (1985) Geological map of Iran. Geological Survey of Iran, Tehran, scale 1:2,500,000

Jamali F, Hessami KH, Ghorashi M (2010) Active tectonics and strain partitioning along dextral fault system in Central Iran: analysis of geomorphological observations and geophysical data in the Kashan region. J Asian Earth Sci 40: 1015-1025

KonON A (2007) Strike-slip faulting in the Kielce Unit, Holy Cross Mountains, central Poland. Acta Geol Pol 57: 415-441

Masson F, Anvari M, Djamour Y, Walpersdorf A, Tavakoli F, Daignieres M, NANKali H, VAN Gorp S (2007) Largescale velocity field and strain tensor in Iran inferred from GPS measurements: new insight for the present-day deformation pattern within NE Iran. Geophys J Int 170: 436-440

Mcquarrie N, Stock JM, Verdel C, Wernicke B (2003) Cenozoic evolution of Neotethys and implications for the causes of plate motions. Geophys Res Lett 30, 2036, doi: 2010.1029/2003GL017992

Meyer B, Le Dortz K (2007) Strike-slip kinematics in Central and Eastern Iran: estimating fault slip-rates averaged over the Holocene. Tectonics 26, TC5009, doi: 10.1029/2006tc002073

Mørk MBE, McEnroe SA, Olesen O (2002) Magnetic susceptibility of Mesozoic and Cenozoic sediments off Mid Norway and the role of siderite: implications for interpretation of high-resolution aeromagnetic anomalies. Mar Petrol Geol 19: 1115-1126

Morley CK, Kongwung B, Julapour AA, Abdolghafourian M, Hajian M, Waples D, Warren J, Otterdoom H, SriSURIYON K, KAZEMI H (2009) Structural development of a major late Cenozoic basin and transpressional belt in central Iran: the Central Basin in the Qom-Saveh area. Geosphere 5: 325-362

Mouthereau F (2011) Timing of uplift in the Zagros Belt/ Iranian Plateau and accommodation of late Cenozoic Arabia-Eurasia convergence. Geol Mag 148: 726-738

Mouthereau F, Lacombe O, Verges J (2012) Building the Zagros collisional orogen, timing, strain distribution and the dynamics of Arabia/Eurasia Plate convergence. Tectonophysics 532-535: 27-60

Nabighian MN (1972) The analytic signal of two-dimensional magnetic bodies with polygonal cross-section: its properties and use for automated anomaly interpretation. Geophysics 37: 507-517

NABIGHIAN MN (1974) Additional comments on the analytic signal of two-dimensional magnetic bodies with polygonal cross-section. Geophysics 39: 85-92
NADimi A (2015) Structural analysis of the Hasan-Robat Marbles as traces of folded basement in the SanandajSirjan Zone, Iran. Geotectonics 49: 554-571

NAdimi A, KonON A (2012) Strike-slip faulting in the central part of the Sanandaj-Sirjan Zone, Zagros Orogen, Iran. J Struct Geol 40: 2-16

Noriega GR, Arrowsmith JR, Grant LB, Young JJ (2006) Stream channel offset and late Holocene slip rate of the San Andreas Fault at the Van Matre Ranch Site, Carrizo Plain, California. Bull Seis Soc Am 96: 33-47

Paul A, Kaviani A, Hatzfeld D, Vergne J, Mokhtari M (2006) Seismological evidence for crustal scale thrusting in the Zagros mountain belt, Iran. Geophys J Int 166: 227-237

Phillips JD (1998) Processing and Interpretation of Aeromagnetic Data for the Santa Cruz Basin-Patahonia Mountains Area, South-Central Arizona, U.S. Geological Survey Open-File Report 02-98: pp 1-98

Radfar J, Amini Chehragh MR, Emani MH (1999) Geological map of the Ardestan. Geological Survey of Iran, Tehran, scale 1:100,000

Radfar J, Kohansal R, Zolfaghari S (2002) Geological map of the Kuhpayeh. Geological Survey of Iran, Tehran, scale 1:100,000

Reid AB, Allsop JM, Granser H, Millett AJ, Somerton IW (1990) Magnetic interpretation in three dimensions using Euler deconvolution. Geophysics 55: 80-90

Reiter F, Acs P (1996-2011) TectonicsFP software: Version 1.6.4, build 1.161 (http://www.tectonicsfp.com)

SAfaei H, TAheri A, VAZiri-Moghadam H (2008) Structural analysis and evolution of the Kashan Fault (Qom-Zefreh Fault), Central Iran. J Appl Sci 8: 1426-1434

Shahabpour J (2005) Tectonic evolution of the orogenic belt located between Kerman and Neyriz. J Asian Earth Sci 24: 405-417

TALEBIAn M, JACKSON J (2004) A reappraisal of earthquake focal mechanisms and active shortening in the Zagros Mountains of Iran. Geophys J Int 156: 506-526

THOMPson DT (1982) EULDPH: a new technique for making computer-assisted depth estimates from magnetic data. Geophysics 47: 31-37

Vernant P, Nilforoushan F, Hatzfeld D, Abbassi MR, Vigny C, Masson F, Nankali H, Martinod J, Ashtiani A, Bayer R, TAVAKoli F, Chery J (2004) Present-day crustal deformation and plate kinematics in the Middle East constrained by GPS measurements in Iran and northern Oman. Geophys J Int 157: 381-398

Zahedi M, Amidi M (1991) The Geological Map of Kashan. Geological Survey of Iran, Tehran, scale $1: 250,000$

Zahedi M, Samadian M, TaAvosian S, Amidi M (1978) Geological map of the Isfahan. Geological Survey of Iran, Tehran, scale $1: 250,000$ 